\title{
"Why is it that here we can be a family, and there we cannot?" How Wider Socio-Institutional Frameworks Shape Experiences of LGB Parenting
}

\author{
Tanja VUČKOVIĆ JUROŠ \\ Interdisciplinary Research Center on Families and Sexualities (CIRFASE), \\ Université Catholique de Louvain, Louvain-la-Neuve, Belgium \\ tanja.vuckovic@uclouvain.be
}

\section{ABSTRACT}

The legal status and social acceptance of same-sex partners' families vary to an astonishing degree, even within the European Union (EU). These differences are sharply reflected in the lives of lesbian, gay and bisexual (LGB) migrants from Central and Eastern Europe (CEE) residing in countries such as Belgium or the Netherlands, where same-sex partners can marry, access adoption and assisted reproductive technologies (ART) services, and acquire legal co-parenting rights. For this group, every visit to a CEE country of origin with a constitutional definition of marriage as a union between a man and a woman, with limited or no access to adoption services, nor to ART or co-parenting rights, highlights the societal and institutional vulnerability of their families. Based on biographical narrative interviews (BNIM) with six LGB migrants from selected CEE countries of origin, raising children with a same-sex partner in Belgium or the Netherlands, this study analyses how differences in wider socio-institutional frameworks shape experiences of LGB parents relating to the formation, display, recognition and acceptance of their families. The findings highlight how the restrictive legal and institutional frameworks not only exclude LGB individuals from full citizenship, but also provide support for the individual-level discrimination of non-heterosexual families. In contrast, inclusive frameworks allow LGB individuals to realize life and family trajectories already accessible to others in society, while also discouraging the expression of individual prejudice. Therefore, the study concludes that the only way to ensure full equality and to protect LGB individuals and their children from stigmatization is to create a fully inclusive socio-institutional framework for non-heterosexual families in which individual prejudice is no longer supported.

Key words: $\quad$ LGB parenting, Central and Eastern Europe, migrants, family, acceptance of same-sex families, socio-institutional differences 


\section{INTRODUCTION}

But one day she's [daughter] gonna have more intelligent questions, and I realize that these are [...] questions where you just go like: "I'm sorry, I have no answer to you, expect that people are idiots." Because you have absolutely no valid response to that, why is it that here we can be a family, and we cannot be a family somewhere else. (Dominika)

The predicament described above, by a Central Eastern European woman raising a child with her same-sex spouse in Belgium, underscores an issue increasingly raised by lesbian, gay and bisexual (LGB) individuals and their families. Even within the European Union (EU), the legal status and social acceptance of same-sex partners' families vary to an astonishing degree. This is well illustrated by the rising visibility of cross-border problems faced by same-sex families - the challenges LGB migrants meet as regards the recognition of their families in various EU states often expose the failings of the freedom-of-movement directive (NELFA, 2018). ${ }^{1}$ Problems may be encountered across a diverse array of EU countries, since countries such as Belgium or the Netherlands - where same-sex couples have been able to marry for more than 15 years and can now also fully access joint and second-parent adoption and legal parenthood - are exceptional, both in Western Europe (WE) and in Central and Eastern Europe (CEE) (Mendos, 2019; Eggert and Engeli, 2015). Still, it is in certain CEE states that some of these challenges faced by families of LGB individuals in Europe can be particularly well highlighted, especially when compared to cases of European-wide outliers such as Belgium or the Netherlands.

This is not to say that CEE countries should be approached uniformly. Even though various studies often claim the presence of a more homophobic public opinion in many CEE countries compared to WE countries (Lottes and Alkula, 2011; Bolzendahl and Gracheva, 2018), looking at the specifics of LGB legislature alone immediately challenges the overly simplistic view of the West-East divide. For example, although no CEE country currently recognizes same-sex marriage, several recognize same-sex partnerships. Slovenia, for instance, also offers same-sex

However, at least some changes may be in progress as the EU member states are expected to implement the 2018 Coman ruling of the Court of Justice of the European Union. This case was brought to the Court by a Romanian citizen whose husband was denied a spousal residence permit as their marriage, registered in Belgium, was not recognized in Romania. The ruling on this case grants same-sex spouses married in an EU state the right to be recognized even in EU countries that do not recognize same-sex marriage (Neidhardt, 2018). 
couples access to second-parent adoption, ${ }^{2}$ which many WE countries do not allow (Mendos, 2019). Similarly, Croatia allows LGB individuals to obtain parental responsibility for their legal partner's child, as regulated through a partner-guardian status (Petrašević, Duić and Buljan, 2017). Nevertheless, it still prevents same-sex couples from accessing in-vitro fertilization (IVF) and joint or second-parent adoption. The latter, however, is often the case in numerous WE countries as well (Mendos, 2019; Waaldijk, 2017). Yet despite all these qualifications, one notable pattern is that certain CEE countries are the only EU members with constitutional provisions defining or protecting marriage as a union between a man and a woman. ${ }^{3}$ Admittedly, in Croatia and Hungary such a constitutional provision co-exists with the legal recognition of same-sex partnership (Mendos, 2019), but these inconsistent legal developments emphasize even more the importance of the institution of "marriage" for the symbolic exclusion, in addition to other exclusions, that the families of same-sex partners face in countries that have considered it necessary to incorporate such heteronormative provisions into their constitutions.

Belgium and the Netherlands should by no means be taken as representatives of the "West" in respect of the recognition of the rights of same-sex families, and many issues exist in these countries as well. Nevertheless, within the EU framework, Belgium and the Netherlands are representative of good practices for the inclusion of same-sex partner families. As such, the socio-institutional frameworks of these two countries can be contrasted with those of EU members that not only limit the rights of same-sex partners and parents, but also institutionally entrench these limitations through a symbolic societal exclusion represented by the constitutional definition of marriage as a union between a man and a woman. Those considered in this study are Bulgaria, Hungary, Poland and Slovakia. These contrasting cases, in turn, can be explored to enhance the understanding of how differences in wider socio-institutional frameworks affect available trajectories and the everyday experiences of LGB individuals and their families; an issue that remains largely understudied. This study aims to at least partially fill this gap. It focuses on the case of LGB migrants from selected CEE countries in Belgium or the Netherlands, whose families are protected in their host countries, but not in their countries of

2 In theory, at least, which is in practice made more complicated by the stipulation that the adoptive parents must be married - which is still not possible in Slovenia (Mendos, 2019).

3 At the time of writing, the EU member states that constitutionally defined or protected marriage as a union between a man and a woman were Bulgaria (Art. 46, https: //www.parliament.bg/en/ const), Croatia (Art. 62, https://www.zakon.hr/z/94/Ustav-Republike-Hrvatske), Hungary (Art. L, https://www.parlament.hu/irom39/02627/02627-0187. pdf), Latvia (Art. 110, http://saeima. Iv/en/legislative-process/constitution), Lithuania (Art. 38, http://Irkt.lt/en/about-the-court/legalinformation/the-constitution/192), Poland (Art. 18, http://www.sejm.gov.pl/prawo/konst/angielski/ kon1. htm) and Slovakia (Art. 41, https: //www.zakonypreludi.sk/zz/1992-460). 
origin. Their parenting experiences expose particularly well how different socio-institutional frameworks shape the formation, display, recognition and acceptance of same-sex families. They also provide a clear illustration of how socio-institutional frameworks matter not only for the full inclusion of LGB individuals, but also for discouraging individual-level discrimination of non-heterosexual families.

\section{FAMILIES OF SAME-SEX PARTNERS AND LGB PARENTING}

Western and particularly Anglo-Saxon researchers have long been interested in LGB parenting. Studies on LGB-parent families emerged in the late 1970 s and early 1980 s and surged in the 2000s. This research mostly examines children's outcomes, LGB pathways to parenthood and experiences of gays' and lesbians' relationships and families (Biblarz and Savci, 2010; Moore and Stambolis-Ruhstorfer, 2013; Biblarz, Carroll and Burke, 2014). However, most empirical analyses do not explicitly situate non-heterosexual families in their socio-institutional frameworks by indicating, for example, how specific laws, or particularities of historical trajectories regarding gender and sexualities, or shifts in public opinion, shape or change experiences of LGB parenting. One of the rare exceptions is a study by Park, Kazyak and Slauson-Blevins (2016), comparing experiences of LGB parenting in two US states with contrasting legal frameworks. This absence is surprising as the literature on sexual or intimate citizenship has long established that changing socio-institutional contexts and new family models are mutually constitutive (Weeks, Heaphy and Donovan, 2001; Plummer, 2002). However, even research that takes an intimate citizenship perspective is typically found to be missing a comparative angle, and it rarely contextually situates non-Western, non-heterosexual families.

The absence of a non-Western perspective in this body of literature creates certain blind spots, as the analyses may fail to identify how non-heterosexual families are constructed differently in non-Western contexts (Richardson, 2017). One notable example of such blind spots, provided by Mizielińska and Stasińska (2018) in their research situated in a familialistic Polish context, emphasizes the more important role played by the family-of-origin in providing support and safety nets for the LGB parents and their children than is usually assumed by the Anglo-Saxon literature. This literature is frequently more focused on (intimate and family) relations of choice (Richardson, 2017; Mizielińska and Stasińska, 2018). Another issue highlighted by non-Western research is the danger of adopting linear models of same-sex family "development" followed by interpreting, for example, CEE developments as a delayed stage or imitation of developments in the West, instead 
of examining how CEE-specific parallel developments interact with adapted social and institutional models, which were often implemented in the context of EU integration (Kulpa and Mizielińska, 2016).

Despite these important insights, non-Western research on non-heterosexual families remains scarce. In the CEE context, for example, only a handful of studies are currently available: ${ }^{4}$ studies from Slovenia (Švab, 2007; Sobočan, 2013), the Czech Republic (Polášková, 2007), Poland (Mizielińska, Abramowicz and Stasińska, 2015) and Croatia (Maričić et al., 2016; Štambuk, Milković and Maričić, this issue; Štambuk et al., this issue). Focusing on the specificities of these cases provides rich and insightful analyses that can provide a thick contextualization of LGB parenting experiences in different CEE countries. However, it can also be useful to take a more abstract look at the shared or missing patterns that characterize various countries in light of the more broadly defined characteristics of socio-institutional frameworks. For example, some specific patterns already emerging from this CEE research highlight changes in perceived parenthood opportunities despite continued institutional obstructions for the new LGB generations (Maričić et al., 2016). Another feature is the discrepancies between the perceived socio-institutional atmosphere and actual personal experiences with the reception of same-sex families in specific CEE countries (Sobočan, 2013; Maričić et al., 2016). One way to further highlight the commonalities of these patterns might also be to compare them with those found in non-CEE countries with contrasting socio-institutional frameworks which is the approach that this study takes. I situate the parenting experiences of LGB migrants from selected CEE countries in both the framework of their everyday lives in their receiving country (Belgium or the Netherlands) and into the framework of their transnational relations in their country of origin. The differences in the patterns of same-sex families' perception and reception between these two different socio-institutional frameworks, as identified by the LGB migrants, are then further sharpened by also connecting them to the specific findings of existing research on LGB parenting in various CEE countries. Such an approach is uniquely well suited for exposing how larger socio-institutional frameworks shape trajectories and everyday experiences of LGB individuals and their families.

4 If other similar studies exist, they remain inaccessible due to language barriers. 


\section{DATA AND METHODS}

This paper's analysis is based on biographical narrative interviews conducted between May 2017 and January 2018 with six LGB parents in Belgium (4) and the Netherlands (2) who come from Bulgaria (1), Hungary (2), Poland (2) and Slovakia (1). This was part of a larger project interviewing transnational LGB migrants who are married and/or raise children with a same-sex partner in Belgium or the Netherlands, and their family members and close friends in selected CEE EU member states where heterosexual marriage is constitutionally protected (MSCA project TOFNITW/TransNorm, 2017-2019). Croatian migrants are part of this larger project, but they were not part of the parents' subsample as I was not able to recruit any eligible Croatian LGB parents. ${ }^{5}$

I recruited the study participants through personal contacts and advertisements on social media and among LGBTIQ and rainbow families' organizations in Belgium and the Netherlands. Recruitment in itself was a challenging process. Both migrants and sexual minorities are hard-to-reach or hidden groups, with no official statistics providing reliable population approximations of either group (Ellard-Gray et al., 2015; Engbersen et al., 2013), let alone of their intersections. The study eligibility criteria further defined the group of interest very narrowly, which additionally severely limited the pool of potential participants. I was therefore reliant on the eligible participants obtaining information about the study, either through advertisements or through an intermediary, and then deciding to reach out to me. Presumably as a consequence of such a recruitment process, the small group of LGB parents who volunteered to participate in the study share many similar characteristics, as described below.

\subsection{Sample, case selection and generalizability}

Six LGB parents participating in this study are CEE migrants aged between their early 30 s and early 40 s, who self-identify as lesbians, gays or bisexuals (four cis-females and two cis-males). After coming to Belgium or the Netherlands, they became involved in a planned parenthood project with their same-sex partner or spouse - through ART for women (the sample includes three biological and one social mother ${ }^{6}$ ), and surrogacy and co-parenting with a heterosexual woman for

5 The remaining two EU members with a constitutional definition of marriage as a union between a man and a woman, Latvia and Lithuania, were excluded from the study due to the feasibility challenges and the financial burdens of a single researcher conducting and organizing fieldwork in two additional countries, thus adding two more languages and sites to the study.

6 Social parents are mothers or fathers who participate in raising a child without a biological link to her/him. For example, these might be the partners of biological LGB parents. 
men (the sample includes one biological and one social father). They were also, at this point or in the past, members of LGBTIQ or rainbow families' organizations or networks. Moreover, the participants in this study were all highly educated - most held a master's degree - and, with one exception, all had a background of working for European institutions or international corporations.

Therefore, the study's participants belong to a specific and, arguably, privileged class profile in the context of their receiving countries. While this certainly means that their experience is not a common or a typical experience of LGB migrants or even LGB parents in Belgium and the Netherlands, it nevertheless allows me to classify this group of (upper) middle class CEE migrants as a critical case whose extraordinary experience may be used to argue that "if it doesn't happen there, it won't happen anywhere" (Patton, 1990: 174). Therefore, while the small size and specific characteristics of this sample preclude any broader generalizations, this study aims to use the strategic nature of this critical case to achieve theoretical generalizability (Gobo, 2008), through highlighting striking patterns or issues of the strongest theoretical interest. To achieve this goal, the sample size is of lesser importance - for as Gobo (2008) highlights and many sociological classics corroborate, small $\mathrm{N}$ can be sufficient for fruitful insights if the cases are well chosen and thoughtfully analysed. In qualitative inquiry, the researcher is not seeking to claim that the patterns of her small sample hold in a population, but to use these patterns to think through why particular issues or experiences are (or are not) shared with others similar to (or different from) the examined group in some key theoretically-meaningful features.

Critical case reasoning has also guided this study's original choice of participating countries. They were selected as examples of the most divergent socio-institutional contrasts in the EU, operationalized via the status of same-sex marriage. Specifically, the constitutional definition of same-sex marriage as a union between a man and a woman in participating CEE countries is taken to represent a strong symbolic exclusion of same-sex families from societal definitions of the family, despite many other variations in selected CEE countries' legal frameworks, let alone in their specific historical and cultural trajectories. From this point of view, the study's findings are also relevant for the Croatian context, as Croatia's notedly homophobic popular opinion (Vučković Juroš, Dobrotić and Zrinščak, 2015) and the constitutional protection of heterosexual marriage place it in the same cluster as the participating LGB parents' countries of origin. This is the case despite Croatia's limited recognition of same-sex partners' parenting rights, established through the "parental responsibility" provision in the 2014 Life Partnership Act, which does currently provide certain advantages to Croatian LGB parents in comparison with LGB parents in other CEE countries participating in this study, where no such rec- 
ognition is available (Mendos, 2019). Belgium and the Netherlands, on the other hand, are characterized by an established tradition of same-sex marriage, legalized in Belgium in 2003 and in the Netherlands in 2001, and, in addition, with almost as long a tradition of full reproductive rights for same-sex partners: the Netherlands has permitted access to both ART and joint same-sex adoption since 2001 and Belgium since 2006 (Eggert and Engeli, 2015). Without denying the importance of Belgian-Dutch differences and variations in CEE contexts, this study, nevertheless focuses on wider patterns shared across participating CEE countries, and contrasted against those shared by Belgium and the Netherlands in terms of socio-institutional provisions for families of same-sex partners.

Coming back to the strategic and theoretically-driven value of the sample used in this study, situating the critical case of participating LGB parents into this framework makes them emblematic of what is arguably the "best-case scenario" possible today in Europe. They are a relatively socio-economically privileged group of migrants situated in socio-institutional contexts currently providing the greatest levels of recognition to families of same-sex partners. At the same time, these migrants living out the "best-case scenario" are intimately aware of how their privileged position in Belgium or the Netherlands sharply contrasts with their possible options in their countries of origin.

\subsection{Interviews and data analysis}

I conducted all the interviews with LGB parents in English in their receiving countries. Interviews were audio-taped and transcribed verbatim. The study was ethically reviewed and approved by both the author's host institution and the funding agency. All participants provided verbal informed consent, and the interview material was later anonymized. The quotations presented in this paper were chosen for their illustrative role and edited for readability. I do not provide any additional information about the participants (such as their country of origin) and I identify the quotations solely via participants' pseudonyms, which were chosen as names common in the several participating countries. The reason for such limited information is that providing it is not necessary for understanding the data, and it would further endanger the confidentiality of this very specific group of participants.

The interviews were conducted using the biographic narrative interpretative method (BNIM) of interviewing (Wengraf, 2001). The main advantage of this unstructured method of interviewing is that it allows the participants to narrate their lives along the lines most personally important to them, while the researcher's assumptions and expectations are temporarily bracketed. The researcher still has an important role in probing deeper into the issues of greatest interest, but nar- 
rative control over the interview rests with the participants. This may often lead to unanticipated new insights. For the purpose of this article, the material from these unstructured interviews was analysed following principles of inductive thematic analysis (Emerson, Fretz and Shaw, 1995), and it was managed in Atlas.ti, the qualitative data analysis and research software. Emergent themes were further organized along the main lines of investigation on LBT parenting in CEE countries, as identified in the literature. Finally, I checked the validity of my interpretations by using a negative cases method, which requires the researcher to actively re-examine the data looking for patterns or instances that contradict their interpretations or conclusions (Rizzo, Corsaro and Bates, 1992; Becker, 1998; Patton, 1990). Such a method is particularly appropriate for qualitative studies using small and strategic samples, since in these types of studies the quantitative evaluation of patterns is often misleading - even those patterns that were identified in only one participant's narrative may be meaningful considering the strategic choice of the interpreted case. In this framework, the identification of negative cases is used to evaluate whether a particular interpretation should be challenged or not. If not, then these findings can be discussed within a framework of theoretical generalizability built not around the repeatability of patterns within a population, but around observations of "key structural features...which are to be found in other cases or events belonging to the same species or class" (Gobo, 2008: 206).

\section{RESULTS: EXPERIENCES OF LGB PARENTING IN DIFFERENT CONTEXTS}

Based on interviews with LGB parents from selected CEE countries in Belgium and the Netherlands, I identified four main themes that show how broader differences in socio-institutional frameworks shape experiences of LGB parenting. In the text below, I discuss each of these four themes - formation, display, recognition and acceptance of same-sex families - in relation to existing research, with a focus on CEE contexts. The first theme, forming families, outlines how context shapes opportunities and expectations for LGB parenthood. The second theme, displaying families, emphasizes how an inclusive context allows LGB parents to live their lives in privacy and "normality," without having to act in anticipation of their families being invalidated. The third theme, recognizing families, identifies how full legal protection for same-sex families places the responsibility for discrimination directly onto the discriminating individuals, who are perceived to be violating wider societal norms. Finally, the fourth theme, accepting families, highlights the tensions between the acceptance of same-sex families with children through personal contact, which is rarely negative, and at the institutional-legal level, which signals the 
wider societal climate. In contexts perceived as restrictive, uncertainty or negative expectations colour the interactions of same-sex families with their environment in ways that are absent in inclusive frameworks where family diversity is a new reality.

\subsection{Forming families}

In the past, most children in same-sex families were conceived in previous heterosexual relationships. Nowadays, however, LGB individuals increasingly plan parenthood in the context of established non-heterosexual identities and relations through, for example, ART, surrogacy or adoption (Patterson and Riskind, 2010). As earlier mentioned, Belgium and the Netherlands are outliers in their fairly inclusive ART and adoption legislation. In most other countries, pathways to LGB parenthood are more open than before, but obstacles to LGB parenthood remain widespread. In such contexts, as seen from UK research conducted in the mid-1990s (Weeks et al., 2001) and US research from the 2000s (Patterson and Riskind, 2010), prevailing narratives of LGB parenthood are narratives of new possibilities that are, nevertheless, often fraught with uncertainty and difficulties, dissuading some from pursuing LGB parenthood. The research from CEE countries such as the Czech Republic (Polášková, 2007), Slovenia (Švab, 2007; Sobočan, 2013), Poland (Mizielińska et al., 2015) and Croatia (Maričić et al., 2016; Štambuk et al., this issue; Štambuk et al., this issue) detects similar patterns of new, though difficult, possibilities. Although some LGB individuals give up on parenthood in the face of many barriers, others increasingly fight against them. For example, in the framework of restricted access to ART, women will go to hospitals abroad, will attempt home-based insemination (Maričić et al., 2016) or will try to find loopholes so as to access ART procedures in their countries illegally (Polášková, 2007). Men, however, face more insurmountable obstacles, since severely restricted access to adoption or surrogacy seriously limits their options (Maričić et al., 2016).

The findings in my study of LGB migrants from selected CEE countries sharply outline how changes in socio-institutional frameworks transform the way in which LGB individuals approach family formation. Primarily, in Belgian and Dutch contexts, narratives of difficult possibility became replaced with narratives of real probability, of new options to pursue trajectories that were sometimes not personally imaginable in migrants' countries of origin.

We decided also to start a family because [...] I saw that in this country it would be possible for me to have a life like any other person, like a normal life, you know, getting married, having kids and all that. And I think I always wanted to have children, but I didn't know how so, in [CEE home country] it wasn't really a reality. I know [...] there are women in [CEE home country] who have kids, 
but that's not a way to have it when you have absolutely no legal protection whatsoever, [...] I couldn't have imagined that in [CEE home country]. (Petra)

This real probability of LGB parenthood is also applicable to men. For them, however, it usually requires both extra effort in collecting information about available options and then an extra investment as some of these options can be costly. For example, Dorian had always wanted to have kids, but he learned about the option of surrogacy abroad by chance and, in pursuing it, he and his future husband had to take out a loan. Although this process required a lot of resources, it was appealing as they could both acquire full parental rights in their receiving country afterwards. The children of Jan, the other father in my study, were born through a co-parenting arrangement with a heterosexual woman. Since his husband is the biological father, Jan's position is more precarious; he is currently not recognized as the legal father. But even this might change in the future, as both Belgium and particularly the Netherlands have shown a willingness to address the legal issue of multi-parenting arrangements (Boone, 2018). In any case, Jan has not reported any issues due to the lack of his "legal father" status.

The real probability of parenthood for LGB individuals in this context can also transform possible scenarios for their relationships. The option of parenthood becomes an issue to be discussed early in the relationship, sometimes even on the first date, as several of my participants noted. The need to discuss this option reveals its newness. A trajectory with children somewhere along the way would be assumed for heterosexual partners. It is still not assumed for same-sex partners, but since it is a real probable option for the future, a discussion is needed early to ensure that potential partners are on the same track.

\subsection{Displaying families}

The previous section illustrated how inclusive legal frameworks in Belgium and the Netherlands allowed LGB individuals who desired children to easily follow parenting trajectories within their same-sex relationships. However, LGB individuals who want to pursue similar trajectories in most CEE countries face not only more numerous obstacles, but they must also struggle with the possibility that their everyday family relationships and practices - their "doing family" (Morgan, 2011; Kuhar and Takács, 2011) - may not be granted legitimacy by others. Therefore, they may be forced to work harder at what Finch (2007) calls "displaying families." This is something that all families do - they do "family things" together (e.g. have a family lunch in a restaurant, take a family trip together, put up photos of their family members in their homes...) and they are recognized as a family (or as a good family) in their 
interactions with external audiences (be that other family members, friends and colleagues or public institutions). However, while all families display their status to others, for some family structures, in certain contexts it becomes more difficult to achieve this external recognition as a commonplace occurrence (Finch, 2007). As a result, these families carry an extra awareness with them of how they display their relationships and everyday practices in interactions with others.

This extra awareness can be identified in the existing CEE research on LGB parenting, which is situated in contexts where families are forcefully defined in a heteronormative way (Mizielińska and Stasińska, 2018), or where people insist, for example, on asking the lesbian-parent families "Where is the dad?" (Sobočan, 2013). Specifically, the extra effort made in displaying families is observable from the insistence on the visibility of non-heterosexual families, which thus becomes a political act. LGB parents in these circumstances often perceive themselves as models for other prospective parents or as educators of their environment (Sobočan, 2013; Maričić et al., 2016). As a result, displaying their families in everyday interactions with others, and challenging others' assumptions of what a family is, can start to be perceived as a responsibility to the community by some LGB parents. In contrast, the possible political undertone of displaying family was no longer felt necessary by LGB parents in my study due to their non-heterosexual families already being validated and legitimized by the legal framework and more widely in Belgian and Dutch societies. Although these LGB parents still regularly encounter heteronormative assumptions regarding the gender of their partners and the structure of their family, they are more likely to approach these situations as corrections of incorrect information, rather than as public assertions of their own family or as opportunities to educate their environment. In this way, these non-heterosexual families in the Belgian and Dutch contexts are allowed to retreat into the private sphere, and to be assumed by others to be just another variation within a "normal" range. As a result, their displays of family are less self-aware in their receiving countries - this is just a part of living their everyday lives. However, the enhanced awareness - relating to their commonplace family practices being on display in a different way - returns in the context of their countries of origin.

(A) bit more conscious about [it] in [CEE home country], definitely more conscious, that we walk hand in hand ... when we walk with [child]... We felt comfortable, I must say, but we were conscious of possible looks. (Jan)

How hard families must "work" for their familyhood to be validated is, then, irrevocably intertwined with recognition and acceptance by others. I now turn to consider this issue in the next two sections. 


\subsection{Recognizing families}

As demonstrated in the previous sections, socio-institutional contexts shape opportunities and pathways to LGB parenthood and affect the political-private divide of same-sex families' everyday lives. This section will further show how legal and institutional recognition shapes the experience of LGB parenthood. A study comparing the impact of legal context on LGB parenthood in two US states shows that families in Nebraska, a state with no legal recognition of LGB parenting, were forced to seek roundabouts and loopholes in order to decrease their legal uncertainty, while their legally recognized counterparts in California reported "living in a bubble" of protection (Park et al., 2016). The experiences of CEE same-sex families more closely resemble the uncertainty of the first example, while the situation of families in my sample echoes the "bubble" experience of Californian same-sex families. For example, reports from Poland (Mizielińska et al., 2015) and Croatia (Maričić et al., 2016) provide numerous examples where same-sex families were not recognized as families, and social mothers were not able to assume responsibility for children in hospitals, kindergartens, schools and similar institutions. In contrast, the accounts of my participants abound with everyday examples of full institutional recognition in their receiving countries, from the fertility clinics and hospitals to nurseries and kindergartens.

Even in the hospital [...] I asked them if [...] we have to do a sort of evaluation with a psychologist [...], they said, "No, we don't do that anymore because now it's normal that two women have a child." That's not something they have to assess or evaluate. [...] And also it had never been an issue in the daycare where he goes to. They were very normal about it, very nice. Even for a Mother's day, [...] they just made two sets of presents. And when it was Father's day, then they asked me like, "What should we do? [...] We can do some other activities." And I said, "Well, he could make something for the grandfather," and then we just give it to the grandfather. And then that's what we did at the end. But they're very normal about it. They didn't make any problems. (Petra)

Although there were exceptions to such examples of recognition, these were perceived by my research participants as expressions of individual prejudice that was not backed up institutionally. While the CEE migrants in this research certainly did not expect that prejudice would disappear, not even in Belgium or the Netherlands, they did identify a shift in the responsibility for discrimination. As one participant phrased it: "The Kingdom of the Netherlands is backing me. And if anything, anyone has a problem with it, fuck you." In the context of strong institutional support for equality, discrimination becomes a personal responsibility - and the individual 
doing it, especially if in a position of authority, is at fault for it. In contrast, in contexts where laws are enforcing inequality, discrimination is institutionally supported. Therefore, it remains the problem of LGB individuals who must find a way of dealing with it, or who have to have "luck" and encounter people who will be supportive in institutional settings. As seen in reports from Croatia, many LGB individuals will indeed encounter such supportive individuals among their social workers, teachers or paediatricians (Maričić et al., 2016). However, this is not something that, in the wider restrictive context, can be expected as a standard procedure. This feeling of uncertainty is also experienced by LGB parents in this study in relation to their CEE countries of origin. Starting from the issue of their children's legal documentation, the lack of recognition for their families is felt in very concrete ways. For example, Dominika's child has a Belgian birth certificate with the names of both of the child's mothers. However, when Dominika attempted to register her child's birth at her country of origin's embassy, she was not able to include her co-parent.

(W)hen I went with that to embassy, going to ask for her birth certificate and then for the passport, I mean, the lady there was very nice, [...] and she said "I'm really sorry but," she said: "You have to put father unknown, just your name." She said: "We can ask if she can have a different, I mean, if she can have both names," but she said most likely not [...]. And, of course, she cannot have her listed as the second parent. So, that already, the fact that she is legally somewhere else, in another country, just mine, and that if something would happen to me, I mean, it can be a problem. (Dominika)

Such differences in institutional and legal frameworks raise serious concerns and challenges for parents in this study. The "bubble" of favourable Belgian and Dutch frameworks can thus also create a feeling of experiencing limitations and constraints, which they are unable to leave, for fear of losing the security granted to them there. This can become evident even at the borders, as in the example below where a family of two women and a child was challenged upon their return to CEE even though their countries of origin are part of the same EU as Belgium and the Netherlands.

Very recently we went to [partner's CEE country] for the Easter holidays, and we are so just used to being us three. So when we approached the passport control, we go all three of us together, with our three passports, and our IDs and we passed through all the time. And we did the same leaving from [partner's CEE country] so we were faced with the [CEE] passport control officer and approached [...] all three of us, [...] giving him the documents. And [the child] was actually in [partner's] arms, not in my arms, [...], but her name is my name, [...] 
cause [...] l'm a single mother in [participant's CEE country]. [...] (T)he officer started saying things like: "But why are you both [here]? It should be only the mother and father" or something like that. It should be only the parents who come here with the passport, to which [the partner] wanted to reply like: "We are the parents," but she didn't say anything, and she just said: "She is the mother," so he saw that the IDs fit together. And, I think he made another comment, like, "Next time you just come one by one." [...] He let us go, of course, but that was the example of the fact you stop thinking about the fact that people might look strangely at two women with a kid coming together and so on. (Dominika)

The everyday Belgian "normality" of their lives has become so reinforced in the life of this family that they did not think about the possibility that the passport control officer might challenge it. However, this challenge of recognition forcefully returns this family from the private to a public sphere and renders the previously mentioned issue of family display full of tensions, whereby they must decide whether to assert their family in the face of authority not recognizing them as such. The tensions and insecurity following from the lack of institutional recognition for families of samesex partners become even more tangible in the scary scenarios that visits home can conjure.

If I have to go to the doctor, well, OK, here it's not a big deal [...], the scenario $[\ldots]$ that crossed my mind, [...] in case I go myself to [CEE home country] with kids, and then something happens, and then they go to the hospital, and then, you know, somebody [...] is telling me: "Look, but you don't have any rights to be here. You are nobody for these kids!" And this is like a nightmare! But, I am aware that formally speaking this is something that could happen. That, actual$l y$, well, somebody with a lot of bad will could call some services, you know, to take care of these kids, as if they were nobody's kids. Ignoring the fact that we are the family... Here, we are in a bit of safety heaven. I went to the doctor, you know, and everything is fine, people are treating us like a family. And that's it. But in [CEE home country] (sigh), I could imagine a lot of situations where this could be an issue. (Gabriela)

Hence, for as long as the protective bubble of Belgian and Dutch socio-institutional frameworks remains relatively exceptional, it also remains double-edged in character since the potential losses make these LGB parents very vulnerable elsewhere. 


\subsection{Accepting families}

Finally, the issue of the institutional context and legal recognition of same-sex families is also linked to wider societal acceptance of same-sex families. In CEE contexts, many LGB parents and their children, particularly those from previous heterosexual relationships, are very selective in disclosing their family status due to perceived or expected negative reactions. Some parents even conceal their family structure in most situations, including interactions relating to school or kindergarten, although LGB parents with children planned in same-sex relationships are typically more open, refusing to compel their (usually still very young) children to lead "double lives" (Maričić et al., 2016; Sobočan, 2013). These tensions between disclosure and the anticipated (lack of) acceptance are very much visible in the accounts of the LGB parents included in this study, whose transnational experiences highlight their situation even more. While the migrants in this study were typically open about their sexual identification in Belgium and the Netherlands, they remained more selective when in contact with people in their countries of origin, usually only disclosing their sexual identification and same-sex marriage to parents or close family members. However, the parents in this study were also all parents whose children were born in the framework of same-sex relationships, and this insistence on their children not living "double lives" - shared by many LGB parents with children planned in same-sex relationships in CEE - features prominently in relations with people in their countries of origin.

Once the child was born, ... I wanted to come out to all my family, even more distant relatives...I had to tell them about it because it was such an important event, I had to explain everything, you know, and that was that I was living with another woman and that we had a child together and all that... They were very supportive and very accepting, I was very positively surprised. ...I had a feeling that having a child kind of increases acceptance. Or they accept you more. Because that's something that's valued by the society, raising a child. So I think I could see that with my family. (Petra)

Petra's account of how her child and her family were accepted by her relatives in CEE was a narrative repeated by most of my participants. There were also exceptions - in one case, the lack of an emotional reaction to a new grandchild led one participant to finally disconnect from an estranged parent. However, in most cases, children were welcomed into the family-of-origin. Furthermore, LGB parents in this study reported no negative experiences during interactions in their CEE countries of origin when they visited with children. This latter point, in fact, is a pattern generally identified in the literature on LGB parenting in CEE. Several 
studies noted a discrepancy between an unfavourable societal climate and interactions on a personal level. For example, a 2006 Italian study identified positive or indifferent reactions from neighbours and co-workers, despite mixed public acceptance of same-sex families (Danna, 2011). Studies from CEE countries such as Slovenia (Sobočan, 2013) or Croatia (Maričić et al., 2016) report a similar pattern, where mainstream homophobic public opinion is not reflected in same-sex families' generally good personal experiences with the people around them. In itself, this is not so surprising - CEE countries are filled with open and tolerant people, just as homophobic people exist all over Belgium and the Netherlands. All these societies value children and, in personal contact with them and their parents, most individuals will likely not be confrontational, even if they oppose or are uncertain about the general principle of LGB individuals having children.

However, in my interpretation, the key difference here is the perceived locus of responsibility for the discrimination identified in the previous section. While personal experiences may not support the anticipated negative reactions, the societies in which LGB individuals do not perceive their families to be institutionally protected and in which they are uncertain whether they will continue to have "luck" in their interactions create an awareness of an unfavourable social context. Therefore, despite their positive personal experiences, my participants do not continue to expect that all the people they encounter while visiting their countries of origin will equally warmly greet them. In contrast, such self-awareness seems to be missing from their interactions in the Belgian and Dutch contexts. The environment there is perceived to be more diverse, and the existence of non-heterosexual families seems to be more firmly entrenched in the "reality" of their everyday lives. In turn, LGB parents view these perceptions as important factors in helping their children understand their families as "normal," as just another variation on family structures.

(I)t's important for the kids to also see it as a reality. I mean, she can see that we are fine and everybody around us is fine, but to also see that there are other families. I mean, now she doesn't care, but eventually she might really notice that there other people [...] have two moms and two dads, or more moms and more dads. [...] So, kind of make it her immediate reality. (Dominika)

The LGB parents in this sample are aware that they may encounter problems and stereotypes in Belgium or the Netherlands as well, and that, when their children are older, they will have to find ways to deal with possibly unpleasant situations. But still, these fears about possible negative future life scenarios in Belgium or the Netherlands are rather vague and mild. In contrast, fears surrounding future acceptance in CEE home countries already include, in some cases, expectations of having to change future behaviour. This is well illustrated by Dorian, quoted below, 
as he expects that the acceptance his family has so far experienced on a personal level in his country of origin might change as their children grow and their "difference" becomes more obvious.

They start talking, so in a year [...] it will be more difficult because [CEE] kids will ask them, "Where is your mum?" Um, so then we'll see how that will [...] work. [...] (S)ame-sex family, especially of guys, you need to be very careful. I mean, after they turn 3 or 4, [...] places will get very limited for a while. Yeah. The way it is. Yeah. I don't think we'll be going to [CEE home country] that often. (Dorian)

\section{DISCUSSION}

Based on interviews with CEE LGB migrants raising children in Belgium or the Netherlands, in this study I have analysed how differences in wider socio-institutional frameworks shape experiences of LGB parents relating to the formation, display, recognition and acceptance of their families. This study's findings highlight how the legal and institutional frameworks that restrict LGB pathways to parenthood and challenge the status of LGB-headed families are not only excluding LGB individuals from full citizenship, but also providing institutional support for the individual-level discrimination of non-heterosexual families. In contrast, LGB-inclusive socio-institutional frameworks allow LGB individuals to realize life and family trajectories that are already accessible to others in society, and they also discourage the expression of individual prejudice.

First, through analysing how same-sex families are formed and displayed in the Belgian and Dutch contexts, I identified that these inclusive socio-institutional frameworks enabled LGB migrants to re-imagine their future and envision family and children with a same-sex partner as a real probability. Although LGB individuals increasingly pursue parenthood in more legally restrictive and often homophobic CEE contexts as well, their narratives betray a struggle against institutional and symbolic exclusion and the possible invalidation of their families by the authorities and the environment (Švab, 2007; Mizielińska et al., 2015; Maričić et al., 2016). In contrast, this study's participants have started to consider the LGB part of their identity as less relevant in their everyday lives (see also Seidman, Meeks and Traschen, 1999, for a similar finding on the declining centrality of LGB identity for individuals no longer forced to live "double lives" in the US context). They see their families as recognized and protected, which allows them to move them back into a private sphere. 
Some have argued (Plummer, 2003; Weeks, 2007) that such a realization of both the right to public recognition and to privacy is a marker of the full inclusion and equality of LGB individuals. This line of thinking stems from the claim that, when LGB individuals are denied reproductive choices or familyhood, their "intimate" matters are unavoidably political, independently of whether actors wish to act politically or not. The existence of such a pattern is also supported by the accounts of LGB parents in CEE who are forced into roles as models or educators (Sobočan, 2013; Maričić et al., 2016). But in conditions of full inclusion, non-heterosexual families can claim equality without "being political" - they are just being families. $^{7}$ The focus on the private sphere, in their particular cases, is completely voluntary. They are not forced into it as possibly the only safe space in which to freely experience family bonds, away from the pressures and stress of possibly negative external reactions. In fact, the private sphere in which the migrants from this study live their lives in Belgium and the Netherlands is not so clearly marked from the public sphere - as seen from the lack of self-awareness as regards displaying their families. In contrast, in contexts in which private space is the only safe space, the division between private and public is very sharp - and every family display in these circumstances can become a political statement. Yet, the full inclusion they experience in Belgium and the Netherlands appears as a fragile commodity for the LGB parents in this study: it remains available only in the "bubble" of their relatively privileged lives in socio-institutional contexts that are still out of the ordinary, even within the EU. Leaving this "bubble" thus carries considerable risks for the recognition and protection of LGB migrants' families, as evident from their visits to CEE home countries that immediately strip them of the "normality" of their family lives and fill them with uncertainty instead.

Second, through analysing how same-sex families are recognized and accepted in the Belgian and Dutch contexts, I have identified that, although inclusive socio-institutional frameworks cannot remove individual prejudice, they can effectively curtail its expression. The LGB parents in this study reported no negative experiences as regards the recognition and acceptance of their families, and this pattern applied to their CEE experiences as well. Likewise, many LGB individuals living in CEE countries also reported positive or at least neutral experiences at the level of personal contact with the environment and institutions (Sobočan, 2013; Maričić et al., 2016). At the same time, however, this study's participants are typ-

Some argue (Richardson, 2017; Roseneil et al., 2013) that "full inclusion" remains illusionary, as the prospect of it is only offered to particular types of LGB-headed families, namely those most closely resembling the mainstream heteronormative model (i.e. monogamous couples). However, since this study focuses on the perspectives of the study's participants and their opportunities to pursue desired trajectories, such discussions remain beyond the scope of this paper. 
ically unproblematically open about their family structure in Belgium or the Netherlands, while CEE residents are much more selective and cautious (Sobočan, 2013; Maričić et al., 2016) - which is the same type of behaviour adopted by this study's LGB migrants in CEE contexts. This difference stems from different expectations supported by socio-institutional frameworks. While many CEE individuals, including those in positions of authority, might be accepting and accommodating, some may not be. However, the normative and institutional framework in many CEE countries supports those expressing individual prejudice. This makes their behaviour a problem that LGB individuals must negotiate. In contrast, when support via the normative and institutional framework is removed, the expression of individual prejudice is unexpected and possibly sanctioned - or, as phrased by one of the study's participants, this becomes the discriminator's problem, and no longer the problem of the LGB individual.

\section{CONCLUSION}

This study has examined how contrasting socio-institutional frameworks affect experiences of LGB parenting among CEE migrants raising children with a same-sex partner in Belgium or the Netherlands. I used this case to identify tensions exposed by migrants residing in two LGB-inclusive countries, but whose CEE countries of origin remain sharply contrasted to their receiving countries as regards the recognition of same-sex marriage and LGB parenting rights. The study's findings demonstrate that the Belgian and Dutch contexts have enabled LGB migrants to pursue families and children with same-sex partners on an equal footing with other members of society and in an environment of legal recognition and protection, which was unimaginable to them in their countries of origin. Such an LGB-inclusive context has further proved effective in curtailing individual expressions of prejudice against the families of same-sex partners. Individual prejudice has not disappeared, but it has been denied institutional and societal support, further adding to LGB parents' perceptions of living "normal" and freely chosen private family lives. However, insofar as such inclusive contexts remain out of the ordinary, the "bubble" of protection and recognition these families experience in Belgium or the Netherlands is restrictive as well, limiting their options to leave. This is highlighted by each visit LGB migrants make to their CEE countries of origin, as such visits expose their societal and institutional vulnerability in contexts that challenge the family status of same-sex families and institutionally support the individual expression of prejudice.

Although the conclusions of this study are limited by the small and very specific sample used, they are nevertheless illustrative of "best-case" scenarios for LGB parenting possible today in Europe - both at the level of inclusive socio-institutional 
frameworks and at the level of the relatively privileged class position of this study's participants within these frameworks. While these are certainly not common nor typical experiences for either LGB parents or LGB migrants, their heuristic value (theoretical generalizability) stems from highlighting patterns in LGB parenting that might be achieved under the most favourable circumstances - and which then further underscore the absences of such patterns in the socio-institutional frameworks of, arguably, the EU's least LGB-inclusive cases: CEE countries with a constitutional protection of heterosexual marriage and limited or no access to adoption, ART or co-parenting rights for same-sex couples. Furthermore, this study is not a truly comparative study - comparisons of similar types of LGB-parent families living in different socio-institutional contexts remain lacking in the research on LGB parenting. Still, this study offers the unique perspectives of transnational migrants "caught" between two worlds: the inclusive world of their receiving countries and the restrictive world of their countries of origin, to which they remain connected emotionally and physically through their extended families. Therefore, these perspectives are possibly even more sensitive to contextual differences experienced in transnational migrants' lives.

Finally, the disregard of differences between participating countries limits the contextual approach that this study has taken. Nevertheless, the analytical choice to focus on the shared features of socio-institutional frameworks that most remarkably pit Belgium and the Netherlands against selected CEE countries is theoretically driven and strategic. It also allows for the implications of this study's findings to be considered in other similar contexts, such as Croatia's context as a CEE country in which a heterosexual definition of marriage is constitutionally protected, and co-parenting rights are limited to guardianship rather than full co-parental recognition. These implications, in turn, are straightforward: socio-institutional frameworks matter at every level, from the level of legal equality to the level of everyday interactions. Therefore, the only way to ensure the full inclusion of LGB individuals and their children, and to avoid their stigmatization, is to create socio-institutional frameworks that fully recognize and protect non-heterosexual families, and in which individual prejudice is no longer supported by all the absences and erasures of other family models and configurations emerging from specific definitions of "family."

\section{FUNDING}

This work has received funding from the European Union's Horizon 2020 research and innovation program under the Marie Skłodowska-Curie grant agreement No 702650. 


\section{REFERENCES}

Becker HS (1998). Tricks of the Trade. Chicago: University of Chicago Press.

Biblarz TJ and Savci E (2010). Lesbian, Gay, Bisexual, and Transgender Families, Journal of Marriage and Family, 72 (3): 480-497. https: //doi.org/10.1111/j.1741-3737.2010.00714. x

Biblarz TJ, Carroll M and Burke N (2014). Same-Sex Families. In: Treas J, Scott J and Richards M (eds). The Wiley Blackwell companion to the sociology of families. Hoboken: Wiley Blackwell, 109-131.

Bolzendahl C and Gracheva K (2018). Rejecting the West? Homonegative Attitudes and Political Orientations in Contemporary Eastern Europe, European Journal of Politics and Gender, 1 (3): 345-366. https: //doi.org/10.1332/251510818X15395098277094

Boone I (2018). Co-parenting Before Conception: The Low Countries'Approach to Intentional Multi-parent Families, Family \& Law, 02: 23-129. https: //doi.org/10.5553/FenR/.000034

Danna D (2011). Homoparentality in Italy: Myth of Stigmatisation? In: Takács J and Kuhar $\mathrm{R}$ (eds). Doing families: Gay and lesbian family practices. Ljubljana: Peace Institute, 95-116.

Eggert N and Engeli I (2015). Rainbow Families and the State: How Policies Shape Reproductive Choices. In: Paternotte D and Tremblay M (eds). The Ashgate research companion to lesbian and gay activism. Routledge, 323-339.

Ellard-Gray A, Jeffrey NK, Choubak M and Crann SE (2015). Finding the Hidden Participant: Solutions for Recruiting Hidden, Hard-to-Reach, and Vulnerable Populations, International Journal of Qualitative Methods, 14 (5): 1-10. https: //doi.org/10.1177/1609406915621420

Emerson RM, Fretz RI and Shaw LL (1995). Writing Ethnographic Fieldnotes. Chicago: University of Chicago Press.

Engbersen G, Leerkes A, Grabowska-Lusinska I, Snel E and Burgers J (2013). On the differential attachments of migrants from Central and Eastern Europe: A typology of labour migration, Journal of Ethnic and Migration Studies, 39 (6): 959-981. https: //doi. org/10.1080/1369183X.2013.765663

Finch J (2007). Displaying Families, Sociology, 41 (1): 65-81. https: //doi. org/10.1177/0038038507072284

Gobo G (2008). Re-Conceptualizing Generalization: Old issues in a New Frame. In: Alasuutari P, Bickman L and Brannen J (eds). The SAGE Handbook of Social Research Methods. London: Sage, 193-213.

Kuhar R and Takács J (2011). Gays and Lesbians (Un)Doing Family - An Introduction. In: Takács J and Kuhar R (eds). Doing families: Gay and lesbian family practices. Ljubljana: Peace Institute, 11-16.

Kulpa R and Mizielińska J (2016). 'Contemporary Peripheries': Queer Studies, Circulation of Knowledge and East/West Divide. In: Kulpa R and Mizielińska J (eds). De-centring Western Sexualities: Central and Eastern European Perspectives. Oxfordshire: Routledge, 23-38.

Lottes IL and Alkula T (2011). An Investigation of Sexuality-Related Attitudinal Patterns and Characteristics Related to Those Patterns for 32 European Countries, Sexuality Research and Social Policy, 8 (2): 77-92. https: //doi.org/10.1007/s13178-011-0038-1

Maričić A, Štambuk M, Tadić Vujčić M and Tolić S (2016). Ja nisam gej mama, ja sam mama: roditeljstvo LGB osoba u Hrvatskoj II'm not a gay mom, I'm a mom. Parenthood of LGB people in Croatia]. Zagreb: Jesenski i Turk. 
Mendos LR (ed) (2019). State-Sponsored Homophobia 2019. Geneva: International Lesbian, Gay, Bisexual, Trans and Intersex Association [ILGA]. https: //ilga.org/downloads/ILGA State_Sponsored_Homophobia_2019_light.pdf (10 June 2019)

Mizielińska J and Stasińska A (2018). Beyond the Western Gaze: Families of Choice in Poland, Sexualities, 21 (7): 983-1001. https: //doi.org/10.1177/1363460717718508

Mizielińska J, Abramowicz M and Stasińska A (2015). Families of Choice in Poland: Family Life of Non-Heterosexual People. Warsaw: Institute of Psychology of the Polish Academy of Sciences.

Moore MR and Stambolis-Ruhstorfer M (2013). LGBT Sexuality and Families at the Start of the Twenty-First Century, Annual Review of Sociology, 39 (1): 491-507. https: //doi. org/10.1146/annurev-soc-071312-145643

Morgan D (2011). Rethinking Family Practices. Basingstoke: Palgrave Macmillan.

Neidhardt A-H (2018). The Coman Case: Extending Free Movement Rights to Same Sex Couples or Protecting Marital Status?, European University Institute, 13 December. https: //me.eui.eu/alberto-horst-neidhardt/blog/the-coman-case-enhancing-free-movementrights-for-same-sex-couples-or-protecting-the-status-of-marriage/ (12 June 2019)

Network of European LGBTIQ* Families Association [NELFA] (2018). Cross-Border Family Disputes: Safeguarding Children's Rights. Brussels: Network Of European LGBTIQ* Families Associations. http: //nelfa.org/inprogress/wp-content/uploads/2018/11/NELFAJURI-hearing-19112018-final-long.pdf (10 June 2019)

Park NK, Kazyak E and Slauson-Blevins K (2016). How Law Shapes Experiences of Parenthood for Same-sex Couples, Journal of GLBT Family Studies, 12 (2): 115-137. https: //doi.org/10.1080/1550428X.2015.1011818

Patterson CJ and Riskind RG (2010). To Be a Parent: Issues in Family Formation among Gay and Lesbian Adults, Journal of GLBT Family Studies, 6 (3): 326-340. https: //doi. org/10.1080/1550428X.2010.490902

Patton MQ (1990). Qualitative Evaluation and Research Methods. Newbury Park: Sage.

Petrašević T, Duić D and Buljan E (2017). Prava istospolnih zajednica u Europskoj uniji s posebnim osvrtom na Republiku Hrvatsku, Strani pravni život, 61 (3): 145-169.

Plummer K (2002). Telling Sexual Stories: Power, Change and Social Worlds. Oxfordshire: Routledge.

Plummer K (2003). Intimate Citizenship: Private Decisions and Public Dialogues. Seattle: University of Washington Press.

Polášková E (2007). The Czech Lesbian Family Study: Investigating Family Practices. In: Kuhar R and Takács J (eds). Beyond the Pink Curtain: Everyday Life of LGBT People in Eastern Europe. Ljubljana: Peace Institute, 201-215.

Richardson D (2017). Rethinking Sexual Citizenship, Sociology, 51 (2): 208-224. https: // doi.org/10.1177/0038038515609024

Rizzo TA, Corsaro WA and Bates JE (1992). Ethnographic Methods and Interpretive Analysis: Expanding the Methodological Options of Psychologists, Developmental Review, 12 (2): 101-123. https: //doi.org/10.1016/0273-2297(92)90005-M

Roseneil S, Crowhurst I, Hellesund T, Santos AC and Stoilova M (2013). Changing Landscapes of Heteronormativity: The Regulation and Normalization of Same-sex Sexualities in Europe, Social Politics: International Studies in Gender, State \& Society, 20 (2): 165-199. https: //doi.org/10.1093/sp/jxt006 
Seidman S, Meeks C and Traschen F (1999). Beyond the Closet? The Changing Social Meaning of Homosexuality in the United States, Sexualities, 2 (1): 9-34. https: //doi. org/10.1177/136346099002001002

Sobočan A (2013). Same-Sex Families (In Slovenia): The New Minority, Calitatea Vietii, 24 (1): 31-46.

Štambuk M, Milković M and Maričić A (2019). Motivation for parenthood among LGBTIQ people in Croatia: Reasons for (not) becoming a parent, Croatian Sociological Review, 49 (2): 149-173. https: //doi.org/10.5613/rzs.49.2.2

Štambuk M, Tadić Vujčić M, Milković M and Maričić A (2019). Pathways to Parenthood among LGBTIQ People in Croatia: Who Wants to Become a Parent and How?, Croatian Sociological Review, 49 (2): 175-203. https: //doi.org/10.5613/rzs.49.2.3

Švab A (2007). Do They Have a Choice? Reproductive Preferences among Lesbians and Gays in Slovenia. In: Kuhar R and Takács J (eds). Beyond the Pink Curtain: Everyday Life of LGBT People in Eastern Europe. Ljubljana: Peace Institute, 217-229.

Vučković Juroš T, Dobrotić I and Zrinščak S (2015). Socijalna distanca i društveno okruženje: manjinske skupine u postkomunističkim i južnoeuropskim zemljama. In: Baloban J, Nikodem K and Zrinščak S (eds). Vrednote u Hrvatskoj i u Europi: Komparativna analiza. Zagreb: Kršćanska sadašnjost, 217-257.

Waaldijk K (2017). The LawsAndFamilies Database - Aspects of legal family formats for same-sex and different-sex couples. Paris: INED. http: //www. LawsAndFamilies.eu (31 January 2019)

Weeks J (2007). The World We Have Won: The Remaking of Erotic and Intimate life. Oxfordshire: Routledge.

Weeks J, Heaphy B and Donovan C (2001). Same Sex Intimacies: Families of Choice and Other Life Experiments. Oxfordshire: Routledge.

Wengraf T (2001). Qualitative Research Interviewing: Biographic Narrative and SemiStructured Methods. Newbury Park: Sage. 


\title{
"Zašto ovdje možemo, a tamo ne možemo biti obitelj?" Kako socioinstitucionalni okviri oblikuju iskustva LGB roditeljstva
}

\author{
Tanja VUČKOVIĆ JUROŠ \\ Interdisciplinarni istraživački centar za obitelj i seksualnost (CIRFASE), Katoličko \\ sveučilište u Louvainu, Louvain-la-Neuve, Belgija \\ tanja.vuckovic@uclouvain.be
}

\section{SAŽETAK}

Čak i unutar Europske unije, zakonski status i društveno prihvaćanje obitelji istospolnih partnera znatno se razlikuju od zemlje do zemlje. Te razlike osobito postaju osviještene u životima LGB migranata iz središnje $i$ istočne Europe (SIE) koji se u zemljama poput Belgije ili Nizozemske mogu vjenčati, dobiti pristup usvajanju i asistiranoj reprodukcijskoj tehnologiji (ART), kao i suroditeljska prava. Toj skupini svaki odlazak u SIE zemlju podrijetla u kojoj je brak ustavom definiran kao zajednica muškarca i žene, a pristup usvajanju, ART-u kao i legalnom suroditeljstvu ograničen ili nepostojeći, jasno ocrtava društvenu i institucionalnu ranjivost njihovih obitelji. Na temelju biografskih narativnih intervjua (BNIM) sa šest LGB migranata iz izabranih SIE zemalja koji odgajaju djecu s istospolnim partnerom/icom u Belgiji ili Nizozemskoj, ovaj rad analizira kako društvene i institucionalne razlike utječu na iskustva LGB roditeljstva vezana uz stvaranje, prikazivanje, prepoznavanje i prihvaćanje njihovih obitelji. Nalazi ove studije ističu kako restriktivni zakonski i institucionalni okviri ne samo da isključuju LGB pojedince iz punoga građanskog statusa, nego i podupiru diskriminaciju neheteroseksualnih obitelji na individualnoj razini. Protivno tomu, uključivi okviri omogućuju LGB pojedincima da ostvare živote i obitelji kakvi su već dostupni ostalim članovima društva te obeshrabruju izražavanje individualnih predrasuda. Stoga ova studija zaključuju kako je jedini način da se ostvari puna jednakost i da se LGB pojedinci i njihova djeca zaštite od stigmatizacije jest stvoriti društveni i institucionalni okvir koji će u potpunosti uključiti neheteroseksualne obitelji te koji više neće podržavati individualne predrasude.

Ključne riječi: LGB roditeljstvo, središnja i istočna Europa, migranti, obitelj, prihvaćanje istospolnih obitelji, društvene i institucionalne razlike 
